\title{
Expansão e desaceleração do mercado privado formal de moradia a partir dos anos 2000 na Região Metropolitana de São Paulo*
}

\author{
Expansion and deceleration of the formal private housing market \\ from the 2000s onwards in the Metropolitan Region of São Paulo \\ Beatriz Mioto [I] \\ Carolina Maria Pozzi de Castro [II] \\ Letícia Moreira Sígolo [III]
}

\section{Resumo}

Examina-se o mercado residencial na Região Metropolitana de São Paulo, considerada laboratório de investigação pela extensão, variedade de perfis municipais e de empresas atuantes, arcabouços institucionais, políticas urbanas e habitacionais. As dinâmicas urbanas imobiliárias são analisadas nos períodos de expansão e desaceleração do setor imobiliário nos anos 2000, atentando para especificidades de processos envolvendo o ambiente construído nos municípios da região. Adota-se uma análise multiescalar com dados macroeconômicos e setoriais, organizando uma periodização para caracterizar elementos da oferta privada de moradia, agentes promotores e estratégias empresariais por período e diferentes mercados (maduros e frágeis), além das tendências gerais. Observaram-se mudanças nas estratégias dos agentes e perfil dos produtos conforme o período de expansão ou desaceleração e porte do município/mercado.

Palavras-chave: mercado imobiliário; indústria da construção; provisão habitacional; preços da moradia; Região Metropolitana de São Paulo.

\begin{abstract}
This study examines the housing market in the Metropolitan Region of São Paulo, which is considered a research laboratory due to its extent, variety of companies and municipal profiles, institutional frameworks, urban and housing policies. The urban real estate dynamics is analyzed in periods of expansion and deceleration of the real estate sector in the 2000s, focusing on specificities of processes involving the built environment in the cities of the region. A multi-scalar analysis was carried out, with macroeconomic and sectorial data, and a periodization was organized to characterize elements of the private housing supply, real estate agents and companies' strategies by period and in different markets (mature and weak), as well as general trends. Changes in agents' strategies and product profile were observed according to expansion or deceleration periods and city/market size.
\end{abstract}

Keywords: real estate; construction industry; housing provision; house prices; Metropolitan Region of São Paulo. 


\section{Introdução: dinâmica econômica e características gerais do setor imobiliário brasileiro a partir dos anos 2000}

Este estudo examina a produção habitacional na Região Metropolitana de São Paulo (RMSP) a partir dos anos 2000, especialmente a dinâmica da oferta de imóveis, enfatizando algumas diferenças relevantes entre os municípios que a compõem. Nesta introdução, lança-se mão de dados macroeconômicos, como de crescimento, emprego, valor adicionado, que mostram a dinâmica geral da economia e do setor da construção civil/imobiliário, embasando a periodização adotada para análise da RMSP apresentada no quadro-síntese ao final da seção. Nas seções que seguem, observam-se os aspectos setoriais vinculados a oferta de imóveis, comportamento das empresas, padrão geográfico, entre outros. Propõe-se analisar a dinâmica/intensidade dos períodos em diferentes municípios, atentando, especialmente, às características diferenciadas de oferta e estratégias das empresas, considerando se elas são de capital aberto/fechado de atuação local/ regional/nacional e, com isso, identificar a importância dos agentes de maior ou menor peso para o setor. Na última seção, apresentam-se algumas conclusões consideradas relevantes sobre as especificidades e tendências da região.

A construção civil é um setor fundamental da dinâmica da economia real. É composto por subsetores, tendo a construção de edifícios destacada participação no seu valor total e ,segundo a Pesquisa Anual da Indústria da Construção, do Instituto Brasileiro de Geografia e Estatística (2015), em 2014 e 2015, ela era igual a $44 \%$ e $47 \%$ respectivamente. Relativamente, embora tenha sofrido transformações técnicas significativas, ainda é um setor considerado intensivo em força de trabalho, sendo o subsetor de edificações um importante vetor de dinamismo do mercado de trabalho urbano. A construção ainda mobiliza uma miríade de segmentos ligados aos insumos de produção, máquinas e equipamentos, acabamento, etc. Além de seus efeitos diretos no emprego e na renda e de encadeamento industrial, somam-se os ganhos conectados ao financiamento e crédito bancário e aqueles derivados da propriedade, ou seja, de natureza rentista (Paulani, 2016). Considerando o período mais recente, destaca-se, também, a crescente imbricação das finanças nas determinações das decisões empresariais e produtivas do setor, fazendo com que novos agentes, como seguradoras, fundos de investimento, bancos de investimento, etc., passem a comandar as decisões e os ganhos.

Essa lógica foi gestada no bojo das transformações gerais do capitalismo, em que a expansão geográfica do capital e a ruptura sistêmica dos anos 1970 propiciaram um impulso inédito à acumulação de ativos financeiros como forma dominante de riqueza (Belluzzo, Tavares e Fiori, 2004). Ao enfrentar a concorrência, os capitais passaram a mobilizar seus investimentos a partir de uma lógica financeira geral, em que a valorização de ativos reais e, principalmente, da riqueza fictícia tem como objetivo aumentar ganhos patrimoniais mobiliários e liquidez. Como colocam Coutinho e Belluzzo (1998), o rápido desenvolvimento das inovações financeiras e os avanços nas tecnologias da informação foram centrais para 0 aumento do volume e o encurtamento dos prazos de negociação de ativos. Nesse cenário, 
o universo de decisão ampliou-se, e as expectativas de aumento dos preços dos ativos provocaram um "efeito riqueza" e uma crescente autonomização relativa entre a valorização financeira e a dinâmica produtiva.

Embora essas relações sejam praticamente universais, sua expressão concreta se diferencia, conforme o padrão de desenvolvimento dos países e os setores econômicos. No caso brasileiro, a dissolução do projeto desenvolvimentista erigido com a industrialização e a ascensão do neoliberalismo, em um momento de crise econômica dos anos 1980/1990, fez com que o rentismo e o patrimonialismo, presentes desde os primórdios da nossa formação, fossem aprofundados. Transformações institucionais e na política econômica também garantiram que a lógica das finanças desse respaldo à ascensão de um novo projeto, baseado em privatizações, na desnacionalização e no esvaziamento das ações do Estado para além da ideia de respaldo ao bom funcionamento do mercado.

Ainda nos anos 1990, especificamente para o setor imobiliário, destacam-se as mudanças no padrão de financiamento imobiliário, a partir das experiências de autofinanciamento (Castro, 1999) nos momentos de crise mais severa e da criação do Sistema de Financiamento Imobiliário (SFI), em 1997 - que passa a conviver com o Sistema Financeiro de Habitação (SFH). ${ }^{1}$ Como destacam Royer (2009) e Fix (2011), o SFI, em consonância com o receituário dos organismos internacionais, constituiu-se sob a lógica de ampliação do crédito via mercado de capitais, transformando-se, paulatinamente, em uma fração do mercado de ativos e de expansão do capital fictício - especialmente através dos Certificados de Recebíveis Imobiliários (CRI).
Embora essa tendência estivesse presente desde as mudanças institucionais nos anos 1990, Cintra (2007, p. 106) mostra que o modelo dos CRIs não proporcionou um aumento significativo do investimento no setor habitacional no período mais recente. Isso se dá, segundo o autor, por problemas de segurança jurídica nos contratos e pela falta de um mercado secundário que garanta liquidez aos títulos lastreados no CRI. Segundo o mesmo autor, manteve-se a segmentação setorial, na qual cabe à Caixa Econômica Federal - com recursos do FGTS financiar a habitação da população de até 12 salários mínimos que, somados aos recursos disponíveis no SBPE (Sistema Brasileiro de Poupança e Empréstimo), formariam o principal funding do setor imobiliário no País.

A comercialização das dívidas e dos títulos atrelados ao mercado secundário no Brasil enfrenta também a "concorrência" dos altos patamares da taxa de juros básica. A taxa Selic $^{2}$ inibe o desenvolvimento dos mercados de títulos privados, pois os títulos da dívida pública garantem alta rentabilidade, alta liquidez e baixo risco. Segundo (2018, p. 1), "0 resultado é um mercado que se define pela especificidade de assegurar, quase sem risco, a reprodução da riqueza financeira, com níveis de taxas de juros e de liquidez elevados". Assim, há iniciativas que alargam o processo de financeirização, mas sem o abandono do modelo de acumulação calcado nos fundos públicos e/ou semipúblicos para produção e na dívida pública para a garantia de ganhos fictícios.

A primeira década dos anos 2000, apesar de estar assentada sobre o mesmo modelo macroeconômico e institucional dos anos 1990, apresentou mudanças na dinâmica de crescimento, que foi relativamente melhor se 
comparado às duas últimas décadas do século XX. A partir da valorização dos preços das commodities exportadas pelo Brasil em 2004, engendrou-se um novo ciclo de crescimento. Tal cenário foi possível, de um lado, pelo bom dinamismo da economia mundial, especialmente da China que puxou as exportações brasileiras. De outro, a partir da desaceleração econômica de 2005 e o processo eleitoral de 2006, que reelegeria Lula, o "consenso neoliberal" que regia as políticas macroeconômicas até aquele momento perdeu espaço para uma visão mais "intervencionista". Esta advogava: pela adoção de estímulos fiscais e monetários para aumentar o crescimento e o potencial produtivo; pelo aumento das transferências de renda e do salário mínimo; e pelo aumento do investimento público e planejamento estatal de longo prazo (Barbosa e Pereira de Souza, 2010).

Assim, entre 2006-2008, em cenário externo favorável até a crise econômica, o País cresceu a taxas maiores que os três primeiros anos de governo e de maneira qualitativamente distinta, com fortes incentivos à demanda interna. 0 incentivo à expansão do crédito junto a um mercado de trabalho mais estruturado potencializou o efeito do consumo e reativou a indústria, principalmente de bens duráveis. Em 2008, com a crise econômica mundial, o PIB apresentou taxa de crescimento negativa $(-0,33 \%)$, colocando freio à continuidade da expansão nas bases descritas anteriormente. A resposta do governo à crise foi a realização de medidas fiscais e monetárias anticíclicas, com o objetivo de evitar a contaminação interna do sistema financeiro e, ao mesmo tempo, recuperar o nível de atividade e manter o emprego. Juntamente ao amadurecimento de investimentos realizados nos anos precedentes, como os do PAC, e as medidas anticíclicas, cujo PMCMV é parte importante, ${ }^{3}$ o PIB de 2010 teve o maior nível de todo o período, com crescimento de $7,53 \%$.

Obviamente, essa dinâmica se relaciona com o setor da construção civil. Como ressaltam Hiratuka et al. (2010, p. 284), especificamente para a indústria, o ciclo expansivo diferenciou-se dos anteriores, não apenas pela sua intensidade e duração, mas principalmente pelo fato de ter sido sustentado, sobretudo, pela demanda interna e pelo peso crescente dos investimentos. Segundo os mesmos autores, o crescimento da formação bruta de capital fixo foi maior que o crescimento do PIB entre 2005 e 2008, com grande participação da construção. Nesse contexto, os investimentos concentraram-se primeiramente na infraestrutura e nos setores industriais exportadores que, depois, extrapolaram para outras indústrias, como o setor imobiliário.

O Gráfico 1 apresenta a variação real do Valor Adicionado Bruto da Construção e do PIB brasileiro, mostrando que o setor acompanha a tendência da dinâmica nacional, com picos de crescimento e de taxas negativas que exacerbam o movimento geral. Os momentos recessivos ocorrem no início do período analisado (2003), o qual se atrela à dinâmica pretérita (do final dos anos 1990 e início dos 2000) e a partir dos efeitos da crise de 2008, quando o setor é levemente mais afetado do que a economia nacional (com taxas, respectivamente de $-0,74 \%$ e $-0,33 \%$ ). 0 movimento negativo também se exacerba a partir de 2012, detalhado mais adiante. Os picos ocorrem em função da conjuntura econômica geral e da dinâmica específica do setor, com a abertura de capitais pelas incorporadoras 


\section{Gráfico 1 - Variação real (\%) do PIB e do Valor Adicionado da Construção Civil no Brasil (2003-2017)}

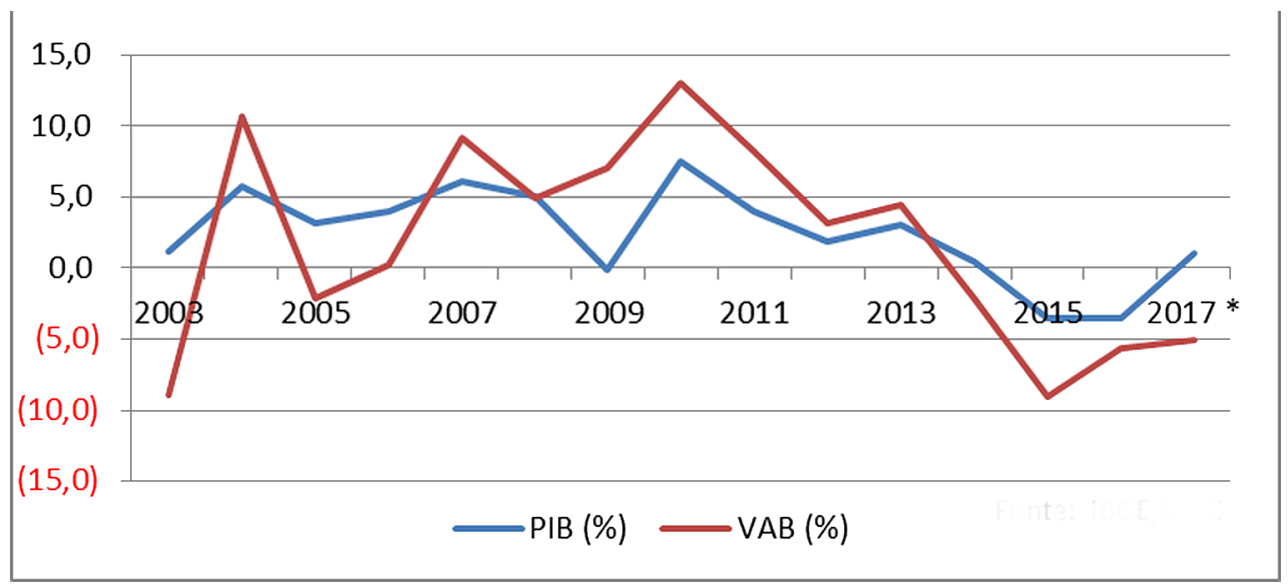

Fonte: IBGE/CBIC.

(principalmente entre 2005 e 2009) e pelas políticas governamentais.

Especificamente para o segmento de Edificações e Incorporação, a entrada de capitais também foi fator importante dos anos 2000. Esse movimento foi intenso na economia brasileira na década de 1990, mas ocorre tardiamente em um setor que, historicamente, havia sido reduto de capitais nacionais. Para Bertasso (2012, p. 124), a entrada desses capitais, principalmente entre 2005 e 2009, não contrariou a lógica da entrada de IDE (Investimento Estrangeiro Direto) no País, muito mais de caráter patrimonial e de ganho de mercado (market-seeking) do que aqueles com o objetivo de modernizar e expandir a base produtiva (greenfield). No caso dos investimentos produtivos, as formas mais relevantes são das Sociedades de Propósito Específico (SPEs), em que as empresas estrangeiras buscam parcerias nacionais para executar as obras. No caso patrimonial, estas são a participação acionária (oferta inicial de ações - IPO), private equity para empresas maiores e venture capital para as médias e menores. Segundo Hall (apud Bertasso, 2012), essa integração ocorre para que se ultrapassem as barreiras técnicas e culturais específicas, o que permite internacionalizar as matrizes sem grandes riscos. No entanto, segundo a mesma autora, entre 2001 e 2009, os capitais que aportaram no Brasil tiveram caráter mais volátil que o IDE em geral, em especial da indústria, com forte participação das incorporações imobiliárias, ou seja, um setor tipicamente rentista.

A abertura de capitais e a internacionalização também colocaram novos agentes na dinâmica imobiliária, como os gestores dos fundos e as corretoras de investimento, que avaliam o desempenho das empresas. Como 
em todos os setores, essa avaliação se dá em função dos resultados de rentabilidade próprios das finanças, a saber, a valorização dos ativos sobre expectativas de maior valorização futura (financeira e operacional futura). Esse cenário, respaldado pelas mudanças no SFI, mencionadas anteriormente, ampliou as formas de apropriação externa das rendas, não só da construção em si, como também da renda da terra. Como mostra Fix (2011, p. 138), a estratégia das empresas perante a abertura de capitais foi ampliar a compra de terrenos na busca de manter, ante os investidores, as possibilidades de efetivar o VGV (Valor Geral de Vendas) prometido no lançamento das ações, sendo os efeitos principais desse processo 0 aumento generalizado do preço dos terrenos e a incorporação de novas áreas (periféricas, rurais, de fronteira, etc.) à dinâmica especulativa do setor imobiliário.

Muitas vezes a impossibilidade de realizar os investimentos reais acaba por atrapalhar os processos de valorização e, como ocorre nesse momento, as empresas encontram-se em piores condições e em nova rodada de "reorganização" patrimonial - como fusões, saída da bolsa, fortes desvalorizações dos seus ativos, etc. (Mioto e Penha Filho, 2018 e Penha Filho e Mioto, 2017). Como aponta Fix (2011), as estratégias das empresas para aumentar o VGV antes do PMCMV contribuíram para a atuação em diversas regiões, principalmente a partir da expansão do segmento para o mercado de baixa renda. Nesse aspecto, o PMCMV foi capaz de alargar a dinâmica expansiva setorial para além da conjuntura econômica favorável, respaldando os interesses das organizações patronais no desenho do programa.
No que se refere ao mercado de trabaIho, segundo Baltar et al. (2010), o crescimento entre 2003-2008 gerou uma espécie de ciclo expansivo do emprego-renda-emprego. 0 setor que teve maior acréscimo absoluto e maiores taxas de crescimento das ocupações foi a construção civil, com 3.386 milhões de ocupados a mais, em 2013, do que em 2003, e taxa de crescimento anual de $4,5 \%$ para o período (Mioto, 2015). Complementando os dados do Valor Bruto da Produção, destaca-se o aumento da participação do subsetor de edificações e incorporação no valor das obras e incorporações do setor da construção civil. Houve tanto um aumento da participação dos setores ligados ao mercado imobiliário no total da construção quanto das construções residenciais no total da construção de edifícios após o PMCMV (2009). 0 impacto entre 2007 e 2012 foi relevante, com ganhos de participação do setor imobiliário no total da construção de $7,15 \%$ e, na produção de edifícios residenciais, de 5,24\% (apud Mioto, 2015).

No entanto, a partir de 2012, as taxas de crescimento caíram substancialmente, mostrando, de um lado, a persistência dos efeitos da crise mundial. De outro, os desdobramentos do período pós-crise mostram a incompatibilidade de uma postura permanentemente mais vinculada à intervenção estatal com o modelo de estabilização e suas prerrogativas monetária e fiscal. Em outras palavras, se, durante 0 segundo governo Lula, vislumbraram-se medidas de cunho desenvolvimentista com a manutenção dos "sólidos fundamentos macroeconômicos", foi porque a conjuntura econômica e financeira internacional ajudou nesse sentido. Findado esse movimento, as mesmas medidas utilizadas (estímulos econômicos, aumento do 
gasto social e do investimento estatal, desonerações, financiamento habitacional subsidiado, etc.) mostraram-se incapazes de manter os níveis de crescimento sem afetar a estabilização exigida especialmente pela forma de inserção externa da economia brasileira. Assim, a os anos de governo Lula e o primeiro governo Dilma devem ser pensados diante dessas contradições das ações "desenvolvimentistas" e a política econômica neoliberal.

0 ciclo expansivo começou a desacelerar em 2012, em primeiro lugar, devido a uma reversão na tendência de alta dos preços das commodities exportadas pelo Brasil, pelo aprofundamento da crise nos países centrais e pela redução da demanda e do crescimento chineses. Em segundo, em função do esgotamento das políticas anticíclicas: seja pelos limites do modelo de crescimento assentado no consumo, seja pela paulatina redução do investimento e do gasto público (Medeiros, 2017). Se o intervalo de 2012-2014 foi de desaceleração do crescimento, com taxa de 0,5\% a.a em 2014, os anos de 2015 e 2016 inauguram um período de recessão, com queda de 3,5\% do PIB nos dois anos, corroborada pelas políticas de austeridade do início do segundo governo Dilma e agravada pelos desdobramentos políticos do processo que lhe imputou o impedimento do cumprimento do seu mandato presidencial (Pinto et al., 2017).

Esse cenário impõe uma crise severa tanto para o emprego/renda/demanda quanto para a produção imobiliária, com quedas significativas do valor adicionado, intensificando a desaceleração da economia brasileira. Isso significou aumento da capacidade ociosa, devolução de imóveis, queda dos estoques de longo prazo constituídos por terrenos e retorno por meio da concentração da produção nos mercados consolidados, tanto na escala regional, principalmente no Sudeste, quanto do ponto de vista metropolitano como se verá mais adiante. Os distratos também são crescentes e, se considerados os dados da Abrainc/Fipe, ${ }^{4}$ entre janeiro de 2014 e fevereiro de 2018, aproximadamente 176 mil unidades foram devolvidas, sendo $45 \%$ correspondentes ao mercado de médio e alto padrão e $34 \%$ de empreendimentos do PMCMV. Já o saldo de emprego na construção civil, segundo o Caged, ${ }^{5}$ é sistematicamente negativo a partir de meados de 2014, chegando a mais de 610 mil desligamentos líquidos no período 2014/2016. No que tange à face financeira desse processo, destaca-se o aumento da fragilidade financeira das empresas, com aumento do grau de endividamento e redução do nível de investimento (Almeida, Novais e Rocha, 2016) e decréscimo no pagamento de dividendos (Mioto e Penha Filho, 2018; Penha Filho e Mioto, 2017). Além disso, essas ocorrências mostram as fragilidades da ampliação do setor imobiliário financeirizado aos moldes do mercado secundário e do SFI, o qual deveria voltar-se às operações imobiliárias residenciais de segmentos médios e superiores do mercado. Em economias relativamente instáveis, com variações abruptas nas taxas de juros de curto prazo, com manutenção de taxas de juros de longo prazo, altas e com variação no nível de renda e emprego, parece óbvia a persistência de uma dependência aos fundings tradicionais com aporte de capitais de baixo custo, como o FGTS e o SBPE, e flexibilizados segundo as conveniências do mercado.

Por último, cabe mencionar algumas questões específicas da RMSP e aspectos relevantes da periodização e metodologia 
adotadas nas seções que seguem. Do ponto de vista econômico, a RMSP foi formada a partir de movimento de concentração espacial da produção e da população. Nessa escala, o limite geográfico é fortemente influenciado pelas relações entre o mercado de trabalho e os deslocamentos diários dos trabalhadores no espaço. Estes são também aspectos centrais da integração urbana, ainda mais em contexto de diferenciação sistemática entre o local de trabalho e o de moradia. Nas palavras de Smith (1998, p. 199), "A diferenciação interna do espaço urbano determina as condições concretas sobre as quais se constrói a expansão urbana". A metrópole, por conseguinte, adquiriu forma específica de expansão, impôs desgaste elevado aos trabalhadores de distintas faixas de renda, principalmente por meio do prolongamento da jornada de trabalho ante as condições de transporte e moradia. E ainda, historicamente, as condições de pobreza impuseram a essa população a necessidade de garantias mínimas de reprodução com centralidade na casa própria, almejada a qualquer custo.

Como se desenvolverá adiante, isso também significou uma forma extensiva de crescimento do mercado imobiliário e de um padrão espacial específico na oferta de moradias, pois combina forte segmentação de mercado, dado que a oferta atende apenas à demanda solvável, e esta tem níveis de preços relativamente maiores, com periferização e segregação. No entanto, ao mesmo tempo que a concentração espacial trouxe problemas e entraves à expansão da produção imobiliária, devido ao preço elevado dos terrenos, pela pressão sobre a infraestrutura em geral e do transporte em particular, também resguardou espaços de valorização perenes.
Do ponto de vista das dinâmicas socioespaciais, ocorreram impactos diversos tanto do ciclo expansivo da incorporação como do PMCMV sobre o território da RMSP. Ressalta-se que a metrópole paulistana, pelo tamanho de seu mercado e pelo patamar de preços da terra e dos imóveis, apresenta constrangimentos contundentes para execução de uma política habitacional. Isso se reflete no fato de mais de $70 \%$ dos empreendimentos contratados pelo PMCMV, até o final de 2013 na RMSP, concentrarem-se nas faixas 2 e 3; e, na Capital, quase $38 \%$ dos empreendimentos eram destinados à faixa 3. Já, nos demais municípios destacados na próxima seção, as participações de atendimento da faixa 1 dependeram das oportunidades de mercado: em Suzano, foram 30,3\%, em São Bernardo, apenas 10,2\% e, em Guarulhos, quase $40 \%{ }^{6}$

Sendo a dinâmica metropolitana específica e relevante, a análise do ciclo de crescimento setorial nessa escala não se resume estritamente às tendências gerais apresentadas. Assim, para dar conta das especificidades, utilizaram-se dados sobre os lançamentos residenciais da Empresa Brasileira de Estudos do Patrimônio (Embraesp) para identificar empiricamente: aspectos das ofertas do mercado formal privado residencial; dinâmica de preços; localização e caracterização dos empreendimentos residenciais; e estratégias das empresas atuantes na região. Cabe destacar que, em que pese o aumento da oferta formal de moradia no período do estudo na RMSP, segundo o Censo/IBGE, entre 2000 e 2010 o número de domicílios aumentou para 1,09 milhões de unidades, sendo somente cerca de $430 \mathrm{mil}(39 \%)^{7}$ produzidos pelo mercado formal (Silva, 2015). 
Adianta-se, nesta introdução, que os dados trabalhados sobre a produção imobiliária residencial mostraram uma alteração fundamental em relação à localização dos empreendimentos, por meio de uma expansão significativa a outros municípios da RMSP para além da Capital, por ocasião da ampliação do mercado do "segmento econômico". ${ }^{8}$ Esta reflete a estratégia dos agentes da produção formal da cidade, a qual foi deslocada em direção aos territórios intraurbanos periféricos dos demais municípios da RMSP, atraída por terrenos grandes e mais baratos, legislação urbanística mais flexível e que estão conectados a São Paulo por importantes eixos viários e rede ferroviária de transporte metropolitano, como Guarulhos, São Bernardo, Santo André, Diadema, Osasco, São Caetano e Barueri. ${ }^{9}$ Com a saída de indústrias, muitos empreendimentos passaram a ocupar terrenos anteriormente utilizados pelas instalações industriais e usos correlatos ou os disponíveis em territórios de mercados pouco consolidados de cidades menos populosas.

Houve municípios e distritos de São Paulo em que a totalidade da oferta do mercado formal foi direcionada ao segmento econômico. Assim, engendrou, com intensidades e características variadas, alterações na morfologia urbana nessas localidades, bem como nos patamares de valores imobiliários praticados, no custo de reprodução social e, por vezes, no perfil socioeconômico de seus moradores. Além disso, as localizações das novas moradias distantes dos locais de trabalho provocaram crescimento significativo de movimentos pendulares, sobrecarregando as já saturadas redes metropolitanas de transporte e a viária, o que, por sua vez, reforçou a constituição do binômio casa própria e automóvel (Sígolo, 2014). Além disso, a chegada da produção imobiliária formal nas periferias consolidadas remonta, uma vez mais, o processo de formação da metrópole de matiz segregador.

Progressivamente emerge uma cartografia da segregação socioespacial na metrópole, com 0 acirramento das disputas por terra urbanizada nestes novos alvos do mercado formal, regiões outrora marcadas pelas dinâmicas imobiliárias informais, deslocadas, agora, para áreas ainda descartadas pelo setor imobiliário. (Ibid., p. 55)

Diante da disponibilidade dos dados e das considerações sobre a dinâmica da economia brasileira, propõe-se a periodização descrita no quadro a seguir, segundo as principais características da oferta habitacional, dos preços e do perfil e estratégias dos agentes promotores na RMSP. 


\begin{tabular}{|c|c|c|}
\hline 2007-2009 & 2010-1012 & $2013-2015$ \\
\hline $\begin{array}{l}\text { • elevação intensa da oferta de novas } \\
\text { unidades, com média de cerca de } 60 \text { mil } \\
\text { unidades/ano; } \\
\text { •cenário de alta liquidez garantido por } \\
\text { fundos públicos e semipúblicos; } \\
\text { - participação relevante de grandes } \\
\text { empresas financeirizadas; } \\
\text { • expansão geográfica da oferta na } \\
\text { RMSP, com aumento da participação dos } \\
\text { demais municípios nos lançamentos; } \\
\text { - das } 166.681 \text { unidades lançadas, } 57 \% \\
\text { localizavam-se no MSP e } 43 \% \text { nos } \\
\text { demais municípios da RMSP. }\end{array}$ & $\begin{array}{l}\text { - continuidade da elevação da oferta, } \\
\text { com pico acima de } 70 \text { mil unidades/ano } \\
\text { (2010); } \\
\text { • elevação de preços das unidades mais } \\
\text { acentuada; } \\
\text { • permanência de participação relevante } \\
\text { de grandes empresas; } \\
\text { - início de retração da oferta no final do } \\
\text { triênio; } \\
\text { - intensificação da expansão geográfica } \\
\text { da oferta na RMSP, com aumento da } \\
\text { participação dos demais municípios nos } \\
\text { lançamentos; } \\
\text { - das } 191.543 \text { unidades lançadas, } 54 \% \\
\text { localizavam-se no MSP e } 46 \% \text { nos } \\
\text { demais municípios da RMSP. }\end{array}$ & $\begin{array}{l}\text { - retração da oferta, com média inferior a } \\
50 \text { mil unidades/ano e declínio a menos } \\
\text { de } 37 \text { mil unidades/ano (2015); } \\
\text { - mudanças na atuação e nas estratégias } \\
\text { dos promotores imobiliários, refletindo a } \\
\text { crise econômica do setor; } \\
\text { - retração da expansão geográfica da } \\
\text { oferta, com redução da participação dos } \\
\text { demais municípios nos lançamentos e } \\
\text { expressiva concentração no MSP; } \\
\text { - das } 146.525 \text { unidades lançadas, } 60 \% \\
\text { localizavam-se no MSP e } 40 \% \text { nos } \\
\text { demais municípios da RMSP. }\end{array}$ \\
\hline
\end{tabular}

\section{A dinâmica do mercado residencial formal na RMSP: preços, produtos e agentes}

Foi com o otimismo típico dos ciclos ascendentes que a demanda reprimida fortaleceu o movimento de ampliação do mercado imobiliário na primeira década dos anos 2000 no Brasil. Nos momentos de maior crescimento, foi central o segmento econômico, que realizava a aquisição da casa própria com as condições facilitadas pela expansão inédita do crédito bancário. No mesmo sentido, os agentes privados viram atendidos os requisitos básicos à oferta de unidades que viabilizava a provisão habitacional pelo mercado, proporcionada pela reforma do SFH no início dos anos 2000. Como abordado anteriormente, além desses fatores, houve a adoção de expedientes propícios à capitalização das empresas de incorporação e construção, quando teve lugar uma crescente inserção de parcelas de terra urbanizada como ativo financeiro aos estoques de terrenos das grandes empresas financeirizadas do setor. Tais processos, além de prescritos em função da avaliação de rentabilidade próprios das finanças, foram impulsionadores da expansão.

Nesse contexto, as quantidades de unidades lançadas na RMSP foram sem precedentes, e seus preços alcançaram patamares diversificados em constante alta. A expansão financeira imobiliária possibilitada pelos recursos de fundos semipúblicos foi associada à crescente oferta de empreendimentos, sendo um importante fator na escalada dos preços de imóveis 
novos e usados, muito acima dos índices inflacionários INCC e IPCA. ${ }^{10} 0$ mesmo fenômeno foi observado em relação ao descolamento da elevação dos preços dos imóveis durante 0 boom em face da elevação do rendimento médio da população, transcorrendo em período no qual se registrou uma melhora significativa do poder aquisitivo das rendas do trabalho, devido à política de recuperação dos salários dos trabalhadores e de formalização do trabalho.

Os preços apresentaram variação nos valores correspondentes aos intervalos dos tetos do financiamento ${ }^{11}$ e foram definidos segundo a maior flexibilidade dada para a aplicação dos recursos do SFH, por meio da introdução de regras mais favoráveis, a exemplo da extensão do período de amortização e a aplicação de juros mais baixos ao financiamento de imóveis mais baratos. A partir de 2009, outros benefícios foram introduzidos, como os subsídios e as garantias ao financiamento, para atender às faixas de consumidores da base da pirâmide social pelo PMCMV, ${ }^{12}$ diretamente vinculados aos recursos do orçamento nacional, ou seja, fundos públicos. Para retratar a evolução dos preços, foi elaborada uma estratificação dos preços nominais das unidades ofertadas pelos promotores privados anualmente entre 2007 e 2015, e, na comparação entre os três períodos de 2007-2009, 2010-2012 e 2013-2015, observaram-se:

1) Espraiamento geográfico dos lançamentos no primeiro e segundo períodos de expansão seguidos; no terceiro período, de declínio da oferta, com encolhimento desse espaço de atuação na RMSP, quando empresas deixaram de ofertar em vários dos municípios para os quais anteriormente haviam se deslocado. Houve exceções em que a oferta cresceu de 2013 a 2015, como na subprefeitura de Itaquera no município de São Paulo (MSP).

2) Crescimento da participação dos distritos centrais mais tradicionais no conjunto dos lançamentos da região, sobretudo no último período analisado. A subprefeitura da Sé, a partir do segundo triênio do ciclo expansivo, assume posição de destaque no conjunto dos lançamentos na Capital ( $2^{\circ}$ lugar), superada apenas pela subprefeitura da Mooca, que já liderava desde o primeiro triênio desse ciclo. Já, no último triênio analisado, essa subprefeitura assume a primeira posição, superando as subprefeituras da Lapa $\left(2^{\circ}\right)$ e da Mooca $\left(3^{\circ}\right)$, o que revela a importância da participação da região central, já presente na segunda etapa da fase expansiva, em que o mercado passou a ofertar produtos diferenciados para um público-alvo específico, distinto, em grande medida, daquele do segmento econômico e que ganha maior importância no ciclo de desaceleração da oferta na região.

3) Oferta de produtos nas faixas de mercado (2 e 3) do PMCMV até 2012, com queda expressiva no último triênio, 2013-2015. Esta é mais expressiva quando computada no conjunto dos demais municípios da RMSP, excetuando-se o MSP.

4) Manutenção ou expansão da faixa superior do segmento econômico (entre $R \$ 170$ mil e $R \$ 350$ mil) ao longo de todo o período analisado, em patamares entre $30 \%$ e $40 \%$ nos dois períodos iniciais, aumentando progressivamente nos anos subsequentes e, a partir de 2011, superando 50\%, nos demais municípios da RMSP, excetuando-se o MSP.

5) Desaparecimento progressivo de produtos mais baratos (abaixo de $\mathrm{R} \$ 170 \mathrm{mil}$ ) ao longo de todo o período analisado, partindo de 
patamares entre $40 \%$ e $50 \%$ no primeiro período, para patamares entre $10 \%$ e $5 \%$ no último, enquanto, no MSP, praticamente desaparecem, atingindo patamares inferiores a $5 \%$.

6) Oferta de produtos mais caros (acima de $\mathrm{R} \$ 350$ mil) menos expressiva somente no primeiro triênio, voltando a crescer, proporcionalmente, desde 2010, representando cerca de 60\% em 2014 na RMSP, e com participação ampliada no MSP, alcançando $70 \%$ da oferta anual em 2013 e 2014. Até mesmo nos demais municípios da região, esse segmento da oferta concentrou 40\% do total em 2014. Em 2015, ela retraiu para $50 \%$ no MSP e para $30 \%$ nos demais municípios.

A casa própria foi a forma de acesso hegemônico no movimento expansivo da produção formal privada, por meio da implantação de grandes condomínios de torres verticais isoladas que ocuparam as novas fronteiras da RMSP, vazios urbanos, lotes remembrados em áreas antigas consolidadas e em áreas com mudança de uso do solo, como as áreas industriais decadentes. Nas áreas periféricas e de ocupação antiga e tradicional, a verticalização, o grande porte e a alta densidade construtiva dos novos empreendimentos contrastaram com o tipo de ocupação do solo existente no seu entorno próximo. Ao longo do ciclo expansivo, o aumento do porte dos empreendimentos foi intenso, apresentando as maiores médias no segundo triênio analisado, entre 2010 e 2012, de 130 unidades na RMSP, sendo de 184 unidades nos demais municípios da região e de 104 unidades na Capital. Por sua vez, as médias das cotas de terreno por unidade residencial foram cada vez mais diminutas, alcançando os menores valores entre 2013 e 2015, já no período de desaceleração e retração da oferta na região, de $30,7 \mathrm{~m}^{2}$ na RMSP, sendo de $28,5 \mathrm{~m}^{2}$ em São Paulo e de $34 \mathrm{~m}^{2}$ no conjunto dos outros municípios da região. Esses parâmetros mostraram uma mudança no porte dos empreendimentos lançados entre o período de expansão e o de desaceleração e retração na RMSP, apesar do progressivo adensamento construtivo com maior aproveitamento dos terrenos verificado ao longo do período analisado.

As empresas adotaram majoritariamente empreendimentos verticalizados na RMSP, correspondendo a uma taxa de verticalização de mais de $90 \%$ em relação ao total das unidades ofertadas. Os empreendimentos verticais que mais se destacaram no mercado, mais conhecidos como "condomínios-clube", foram generalizados em diferentes nichos de ofertas, das mais caras às mais "econômicas" (Sígolo, 2014; Castro e Shimbo, 2011). Observou-se que o tipo de empreendimento que era peculiar de São Paulo e de algumas cidades maiores se generalizou na região, principalmente com a presença dos grandes promotores imobiliários. As grandes empresas atuantes no boom aplicaram parâmetros construtivos, arquitetônicos e padrões de custos e preços, conforme modelos que lhes correspondiam às marcas de produtos imobiliários, de linhas padronizadas direcionadas a nichos de mercados específicos. A partir das novas estratégias dos agentes imobiliários, os resultados no território da metrópole foram influenciados pela forma como os recursos financeiros foram atribuídos e como o poder público fez a gestão do território.

As maiores protagonistas do boom imobiliário foram as grandes empresas do setor que promoveram a abertura de capitais impulsionada por um fluxo de investimento estrangeiro direto inédito e se que tornaram 
sociedades anônimas. Nesse processo, entre outras estratégias adotadas por elas, houve a consolidação de uma política de formação de bancos de terras visando à realização presente e futura de empreendimentos, de modo a apresentar uma melhoria do próprio desempenho ante os investidores. A consolidação dessas empresas no mercado financeiro também guarda relação com os processos de concentração e centralização de capital, resultando em: diversificação geográfica e de portfólio de produtos padronizados oferecidos às várias faixas do mercado, ganho de talento gerencial, reputação em mercados locais e ganhos de escala e formação de bancos de terras. Grande parte dessas grandes empresas se voltou ao segmento econômico do mercado até então pouco atrativo a elas. Para isso, elas tiveram que promover alterações na sua estrutura administrativa e societária e nas estratégias do modelo de negócios e da sua produção em si. Algumas criaram empresas subsidiárias ou como "segunda linha" para atuarem no segmento econômico, outras estabeleceram processos de joint ventures e, ainda, houve um processo de aquisições de construtoras menores com experiência em construções populares (Castro e Shimbo, 2011).

Em 2007, as 10 primeiras empresas que mais lançaram unidades habitacionais na RMSP foram responsáveis por $44,4 \%$ do total de unidades e por $43,2 \%$ do total do Valor Geral de Venda (VGV), sendo $15 \%$ deste direcionado ao segmento econômico. Oito dessas empresas eram de capital aberto. Já, em 2012, as 10 maiores responderam por $34,5 \%$ e $37 \%$, respectivamente, sendo $5 \%$ desse VGV direcionado ao segmento econômico. Nove dessas empresas eram de capital aberto. E, finalmente, em 2015, as 10 maiores responderam por $35 \%$ e $28 \%$, sendo $12 \%$ desse VGV direcionado ao segmento econômico, mostrando a recuperação do espaço desse segmento do mercado na metrópole e o interesse das empresas devido à solvabilidade garantida pelo financiamento. Seis dessas empresas eram de capital aberto. Comparando-se os anos de 2007 e 2012, verificou-se o arrefecimento da concentração da oferta entre as dez maiores, e, em 2015, esta se intensificou. Em 2012 e 2015, constatou-se a gradual redução da participação das grandes empresas de capital aberto no mercado da RMSP. ${ }^{13}$

A Figura 1 apresenta o conjunto dos lançamentos na RMSP de 2000 a 2015 segundo a periodização adotada.

\section{A continuidade do boom imobiliário residencial na RMSP a partir do comportamento da oferta e dos agentes atuantes em cinco zonas de estudo}

A análise multiescalar proposta articula as dinâmicas econômicas às socioespaciais, uma vez que considera que as segundas desempenham um papel ativo não sendo apenas "receptáculo" ou "reflexo" das primeiras. Dadas as diferentes condições do território e da sociedade na região metropolitana, emergem formas produtivas híbridas e arranjos específicos na estrutura da provisão privada formal da moradia nas distintas parcelas desse território. Orientada por essa perspectiva, a análise se volta a zonas de diferentes configurações 
Figura 1 - RMSP: lançamentos residenciais verticais período de 2000 a 2015

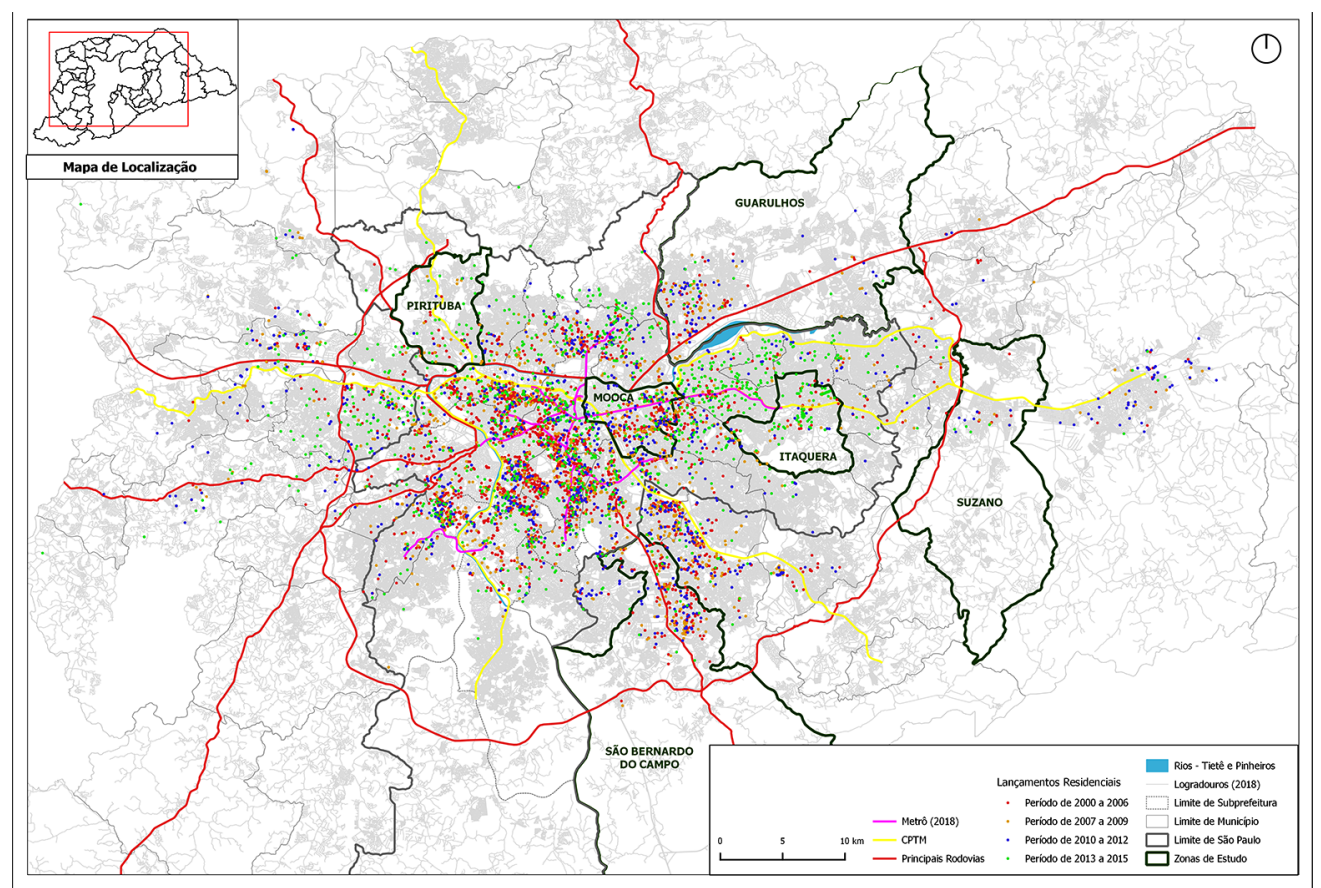

Fonte: elaboração própria com dados Embraesp.

socioespaciais dos períodos de expansão e de desaceleração da oferta habitacional a partir da segunda metade dos anos 2000. As zonas de estudo foram selecionadas devido a sua importância no contexto do boom imobiliário residencial, ou seja, durante o ciclo expansivo da oferta habitacional formal na RMSP.

Em cinco zonas de estudo - as subprefeituras de Itaquera e da Mooca e os municípios de Suzano, São Bernardo do Campo e GuaruIhos -, as dinâmicas do mercado e da oferta foram analisadas, o que permitiu desenvolver o conhecimento de como, mesmo sob a dominância financeira presente nos ciclos recentes de expansão, de desaceleração e de retração da oferta formal privada de moradia na RMSP, inúmeros elementos locais repercutiram nas estratégias empresariais como entraves e benefícios e condicionaram a acumulação e a valorização imobiliária. Esses elementos locais e regionais com repercussão nas diferentes dinâmicas imobiliárias foram definidores na seleção das zonas de estudos.

Entre as zonas selecionadas, foram identificados dois grupos, cada um deles caracterizado por categorias de mercados segundo volume da oferta e por patamares de preços de imóveis ofertados distintos.

No primeiro grupo se encontram as zonas cujos mercados se apresentam mais frágeis; 
ou seja, tanto durante o período de expansão quanto de retração da oferta residencial na RMSP, tiveram poder de atração limitado sobre os promotores imobiliários residenciais. São elas: as subprefeituras de Itaquera e o município de Suzano. Em que pese o crescimento apresentado em Suzano, sobretudo no segundo triênio, de 2010 a 2012, do boom imobiliário residencial deflagrado na região, é possível afirmar que este se trata de um mercado frágil, cujas estruturas de provisão habitacional se apresentam com limitado enraizamento local, o que compromete a perenidade na oferta formal da habitação no município.

No segundo grupo foram incluídos os municípios de Guarulhos e de São Bernardo do Campo e a subprefeitura da Mooca, considerados mercados já consolidados desde os ciclos anteriores de expansão do mercado residencial formal, que mantiveram uma participação importante no conjunto dos lançamentos residenciais na RMSP, bem como apresentaram intensa valorização imobiliária, sobretudo durante 0 período de ampliação da oferta formal de habitação na região, e que, a despeito da queda observada nos lançamentos a partir de 2012, permaneceram ocupando posição de destaque no conjunto dos lançamentos da metrópole paulistana. Durante os dois triênios do ciclo expansivo, Guarulhos ocupou a primeira posição entre os municípios da RMSP, excetuando-se a Capital, com maior participação no conjunto das unidades lançadas na região, seguido por São Bernardo do Campo, na segunda posição. Já, ao longo do período de desaceleração, entre 2013 e 2015, Guarulhos assumiu a segunda posição, superado por Osasco, enquanto São Bernardo ocupa o quarto lugar, superado, discretamente, por Santo André.
Na subprefeitura de Itaquera, região de conjuntos habitacionais da Cohab implantados desde a década de 1970, a recente e nova produção verticalizada de mercado ficou concentrada no centro local e em suas adjacências imediatas, mesmo possuindo glebas maiores situadas no Parque do Carmo, cujo parcelamento existente deriva de ocupação por chácaras. A valorização imobiliária alavancada pela implantação do estádio oficial da Copa do Mundo de Futebol de 2014, no princípio, desde que foi anunciada a construção da arena em 2010, foi positiva para a dinamização do mercado, mas não teve fôlego para prosseguir. Os preços elevados não se mostraram compatíveis com as expectativas dos compradores com poder aquisitivo para tal, na maioria de fora do distrito, que passaram a comparar a oferta da região com outras situadas nas vizinhanças mais infraestruturadas. Essa valorização especulativa engessou o mercado de imóveis usados na região, pelos patamares elevados de preço de oferta de novos, impactando até mesmo os preços dos apartamentos nos antigos conjuntos da Cohab-SP ${ }^{14}$ já regularizados, predominantes na região, que também se beneficiaram dessa valorização. Por sua vez, vetores de expansão do capital imobiliário no território da metrópole direcionaram-se acompanhando a ampliação das infraestruturas urbanas com a abertura de eixos de mobilidade urbana, para a melhoria na acessibilidade da região. De forma extensiva, para o mercado na RMSP, as expectativas quanto aos impactos positivos da implantação das obras de complexos viários se voltaram à presença do Rodoanel Governador Mário Covas e, ainda na Zona Leste, à existência de novos eixos e ligações viários, potencializadores do fomento ao desenvolvimento econômico 
de Itaquera, como o complexo viário avenida Jacu-Pêssego/Rodovia Nova Trabalhadores que corta a região.

A oferta de unidades habitacionais (UHs) novas, ao longo do ciclo de expansão da oferta formal de habitação, não acompanhou a dinâmica municipal ou metropolitana. Ao contrário do esperado, a participação de Itaquera na produção do MSP diminuiu após 2006, de 2,7\% em 2007-2009, para 2,3\% em 2010-2012; e, quando se imaginava que se retrairia ainda mais, no último triênio (2013-2015), aumentou para 2,5\%. 0 volume de unidades lançadas, que foi de cerca de 2.500 UHs, nos dois triênios do boom, saltou para mais de $3.500 \mathrm{UHs}$ no último. 0 porte médio dos empreendimentos lançados foi o menor das cinco zonas analisadas, com variação de 78 UHs (2007-2009) e 62 UHs (2010-2012), despencando para 33 UHs por empreendimento no último triênio. Esse movimento revela uma tendência semeIhante à observada em Suzano, apresentada a seguir, devido à maior presença relativa de lançamentos de empreendimentos horizontais, cuja participação passou de $12 \%$ e $16 \%$ para $22 \%$. 0 consumo médio de terreno por unidade quase não variou ao longo do período analisado, mantendo-se em cerca de $45 \mathrm{~m}^{2}$ e retraindo para $38,5 \mathrm{~m}^{2}$, apesar do aumento relativo das unidades horizontais. Nesse sentido, pode-se afirmar que o aumento da oferta formal de moradia em Itaquera, entre 2013 e 2015, durante o ciclo de retração, foi parcialmente "puxado" por empreendimentos horizontais.

Ao longo do primeiro triênio, entre 2007 e 2009, as unidades lançadas em Itaquera enquadraram-se nas faixas de preço mais baratas, entre $\mathrm{R} \$ 65 \mathrm{mil}$ a $\mathrm{R} \$ 130 \mathrm{mil}$, e apenas $17 \%$ apresentaram preços superiores a $\mathrm{R} \$ 130 \mathrm{mil}$.
De 2010 a 2012, ocorreu um aumento acentuado nos preços dos lançamentos na subprefeitura e desapareceram as unidades de menor preço. Em 2010, do total, mais de $90 \%$ das UHs lançadas tinham preço superior a R\$130 mil, mas somente $15 \%$ eram superiores a $\mathrm{R} \$ 170$ mil. Em 2011, não houve mais lançamentos com preços inferiores a $\mathrm{R} \$ 130$ mil, e as unidades de preços superiores a $\mathrm{R} \$ 170$ mil passaram a representar mais de $20 \%$, alcançando mais de $60 \%$ em 2012. No triênio seguinte (20132015), assistiu-se, ao lado do aumento da oferta, à intensificação da elevação dos preços das unidades lançadas. Em 2013, as unidades com preços inferiores a $\mathrm{R} \$ 170$ mil reduziram-se a menos de $2 \%$, desaparecendo nos anos seguintes. Nesse triênio, as unidades concentraram-se nas faixas de mercado do PMCMV e nos patamares superiores do segmento econômico, com raríssimos lançamentos com preços superiores a R\$350 mil. Se, durante o ciclo de expansão, a oferta formal de moradia em Itaquera pouco se alterou, durante o ciclo de retração, contrariando o movimento observado nas demais zonas analisadas, ela se aqueceu. Verificou-se, na oferta desse período, que quase a totalidade dos lançamentos se enquadrou nos tetos das faixas de mercado do Programa.

Em Itaquera, de 2007 a 2009, atuaram apenas 20 empresas que lançaram 2.572 UHs; de 2010 a 2012, 24, respondendo por 2.412 UHs; e de 2013 a 2015, 61; com 3.596 UHs lançadas, revelando um aumento significativo na quantidade de promotores atuantes, na ordem de quase três vezes, além de maior presença de pessoas físicas atuando na incorporação local. Ao longo do ciclo de expansão, houve uma crescente concentração dos reduzidos lançamentos em um número menor de empresas: 
as dez primeiras empresas concentraram 93\% das unidades lançadas, entre 2007-2009, e $89 \%$ no triênio seguinte. E também ocorreu maior participação das três primeiras, que responderam por $58 \%{ }^{15}$ e $57 \% .{ }^{16}$ Já, no último triênio, entre 2013 e 2015, houve redução da concentração tanto entre as 10 quanto entre as três maiores, que responderam por $73 \%$ e $40 \%,{ }^{17}$ respectivamente. Em todos os períodos, havia empresas de capital aberto entre as três primeiras. ${ }^{18}$ Todavia, após o ciclo expansivo da oferta na região, parte das empresas de capital aberto deixou de atuar em Itaquera. ${ }^{19}$

0 município de Suzano, com poucos lançamentos nos anos 1990, viu aumentar significativamente a oferta formal de habitação, especialmente a partir de 2007, estendendo esse movimento ascendente até 2012, quando se inicia um período de forte retração nos lançamentos residenciais no município. 0 município constituiu-se como lócus de significativa produção de habitação social e do segmento econômico enquadrada no PMCMV e faz parte do vetor leste de expansão do mercado popular. A atração a essa produção popular foram os terrenos ainda mais baratos que em outras regiões da RMSP, posto que, até então, não havia interesse do mercado imobiliário formal em atuar no município, além da oportunidade de liquidez de produtos populares garantida e, também, da acessibilidade promovida pela linha de trem, que se apresenta como um dos elementos indutores dessa expansão, ainda que tal mobilidade seja marcada por sérias limitações.

Acompanhando o crescimento da oferta, houve 0 aumento do porte dos empreendimentos lançados em Suzano, de 106 UHs por empreendimento, entre 2000-2006, para 206 UHs, entre 2007-2009, e para 205 UHs, entre 20102012, e, em seguida, retraindo para $56 \mathrm{UHs}$, entre 2013 e 2015. As cotas de terreno por unidade mantiveram-se relativamente elevadas ao longo de todo o período analisado, a maior entre as cinco zonas estudadas. Esta foi ampliada em decorrência de uma presença maior de unidades horizontais, sobretudo no último triênio (2013-2015), em que se observam a queda na oferta de habitação e a redução da participação das grandes incorporadoras, que foram protagonistas do ciclo de expansivo da oferta formal de moradia, com produtos enquadrados no segmento econômico, sobretudo nas faixas de mercado do PMCMV.

No município, houve uma oferta contínua e expressiva de unidades de preço inferior a $\mathrm{R} \$ 130$ mil, representando 90\% dos lançamentos, em 2007, e mais de $60 \%$ nos anos subsequentes até 2011. Nesse período, também houve diversificação na oferta com o incremento de unidades de preço entre $R \$ 130$ mil e $R \$ 170$ mil, que, somadas, abarcavam quase a totalidade dos lançamentos, ou seja, 97\% em 2009, 78\% em 2010 e 86\% em 2011. Em 2012, as unidades de preço inferior a $\mathrm{R} \$ 130$ mil praticamente desapareceram, o que coincide com a mudança do teto do financiamento nas faixas de mercado do PMCMV para R\$190 mil. Nesse ano, os preços dos lançamentos deslocaram-se para patamares mais elevados, sendo ofertadas unidades de preço entre $\mathrm{R} \$ 350$ mil e $\mathrm{R} \$ 500$ mil, inexistentes no município até então. Em acelerado declínio desde 2012, no último triênio analisado (2013-2015), a oferta passou de 273 UHs, em 2013, para apenas 28 UHs, em 2015, assentando-se quase que exclusivamente nos patamares superiores do segmento econômico, entre $R \$ 225$ mil e $R \$ 350$ mil. 
Em Suzano, de 2007 a 2009, atuaram quatro empresas que responderam por 1.443 UHs; de 2010 a 2012, sete que lançaram 2.665 UHs e, de 2013 a 2015, cinco que promoveram apenas 517 UHs. As três primeiras colocadas responderam por $97 \% 20$ em 2007-2009; $82 \%{ }^{21}$ em 2010-2012 e 87\%22 em 2013-2015. Observou-se que, do primeiro para o segundo triênio, houve uma desconcentração da produção, mediante crescimento da oferta e, em ambos os períodos, atuaram empresas de capital aberto ou a elas associadas entre as três primeiras colocadas. ${ }^{23} \mathrm{Em}$ face das poucas empresas concorrentes, pode-se concluir que o pequeno mercado de Suzano foi controlado pelas grandes no ciclo de expansão. Já, no último triênio analisado, paralelamente à redução, nota-se um pequeno aumento da concentração da oferta entre as três maiores empresas, em relação ao triênio anterior, e que todas as cinco empresas atuantes ingressaram no município nesse último período; nenhuma delas era de capital aberto e mais da metade dos lançamentos foi promovida por empresas de pequeno porte atuantes na Região do Alto Tietê.

0 município de Guarulhos, depois do município de São Paulo, é o principal em população, empregos e em número de unidades lançadas, até 2013, quando é superado por Osasco. As transformações no espaço urbano e construído fizeram com que o patamar de participação do município nos lançamentos residenciais da metrópole paulistana se alterasse profundamente a partir de 2007, quando correspondeu a $10 \%$ desse total. No período de 2013 a 2015, passa a ocupar o segundo lugar no ranking, após apresentar queda na participação no total de unidades ofertadas na RMSP, respondendo por 6,1\%. 0 interesse especial em investigá-lo decorreu da localização privilegiada em relação à Capital, do papel da regulação urbanística adotada pela administração pública municipal, menos restritiva do que a de São Paulo, e, ainda, dos aspectos específicos do desenvolvimento urbano relacionados à presença do aeroporto internacional, dos serviços de logística e da indústria. Ademais, as disputas pelo uso do solo para serviços de logística atingiram importantes eixos viários regionais.

Destacou-se, ao longo de todo o período analisado, o porte dos empreendimentos, muito ampliado em Guarulhos, pois, nos três triênios, o número médio de unidades por empreendimento foi superior a 250, o maior das cinco zonas analisadas. A verticalização, sempre superior a $90 \%$, atingiu seu máximo entre 2010 e 2012, com 98,6\% das unidades lançadas, acompanhada da diminuição da cota de terreno por unidade, de $25,3 \mathrm{~m}^{2}$. No último triênio, ocorreu a redução da oferta e o aumento discreto no porte dos empreendimentos. A cota de terreno aumentou acentuadamente a $49,4 \mathrm{~m}^{2}$, o que refletiu em uma menor parcela de unidades em empreendimentos verticalizados, de 92,8\%, a menor desde 2007 no município e entre as três zonas analisadas de mercado mais consolidado.

Ao longo do ciclo expansivo, assiste-se ao ingresso das grandes empresas, capitalizadas e de capital aberto no município, as quais trouxeram novos patamares de preço semeIhantes aos de São Paulo, bem como promoveram mudanças nos padrões de ocupação, tipos e volumes ofertados. Desde o início do boom (2007-2009), constatou-se um crescente aumento da demanda local e originária da Capital, que impulsionou a oferta de imóveis novos ocupando grandes glebas, de preços 
mais baratos, entre $\mathrm{R} \$ 65$ mil e $\mathrm{R} \$ 170$ mil. Esta alcançou seu ápice em 2009, com $80 \%$ do total das unidades lançadas. A partir de 2010, houve uma retração dos lançamentos mais adequados aos tetos do PMCMV. Paralelamente, cresceu a participação das faixas de preço entre $R \$ 170$ mil e $R \$ 350$ mil, o que denotou o encarecimento dos imóveis ofertados, dados os lançamentos nesse intervalo em 2011 (71\%) e em 2012 (50,4\%). Em 2012, a oferta acima de $\mathrm{R} \$ 350$ mil cresceu, abarcando $30 \%$ do total, demonstrando uma elitização. De 2013-2015, quando houve forte redução do financiamento e alteração nos tetos do PMCMV, aliada à crise econômica, o mercado encolheu e cessou a ampliação aos segmentos de mais baixa renda, e a oferta anual declinou de quase 5.000 a 900 UHs em 2015. Destaca-se, nesse período, a consolidação da oferta de unidades de preço entre $R \$ 170$ mil e $R \$ 350$ mil, enquadradas nos segmentos econômico e médio, e a ausência de oferta de preço superior a $\mathrm{R} \$ 500 \mathrm{mil}$.

Em Guarulhos, de 2007-2009, houve participação de 36 empresas nos lançamentos de 16.402 UHs e, destas, 11 eram empresas de capital aberto que responderam por $65 \%$ do total das unidades lançadas. As três maiores juntas, todas de capital aberto, responderam por $38 \%$ delas. De 2010 a 2012, foram lançadas 17.596 UHs com a participação de 43 empresas. A concentração da oferta foi capitaneada pelas empresas de capital aberto, devido a uma presença contínua delas no mercado de Guarulhos. Além disso, houve grande descontinuidade na atuação das empresas de capital fechado, e somente três empresas desse tipo atuaram nos três períodos analisados. De 2013 a 2015, participaram dos lançamentos, em Guarulhos, 25 empresas que responderam por $8.968 \mathrm{UHs}$; a presença de empresas de capital aberto foi menor do que nos períodos anteriores, com a participação de apenas quatro delas. ${ }^{24} \mathrm{Com}$ a redução da participação das grandes empresas de capital aberto, verificou-se uma menor presença de arranjos produtivos de empresas associadas, e disto decorreram mudanças nas estratégias produtivas, financeiras e locacionais. 0 ano de 2015 destacou-se pela acentuada retração dos lançamentos, foram apenas três empreendimentos, totalizando 907 UHs. Após o período de boom, parte significativa das empresas de capital aberto deixou de atuar em Guarulhos. ${ }^{25}$

0 município de São Bernardo do Campo é subsequente a Guarulhos, em volume de produção, nos anos 1990 e início dos anos 2000. Participou com 7,2\% do total de unidades lançadas na RMSP entre 2007 e 2009, e representou somente 4,6\% entre 2010 e 2012, sem recuperar tal participação ao longo do último triênio analisado, entre 2013 e 2015 . Em contexto de declínio na oferta de unidades em 2015, no entanto, São Bernardo superou Guarulhos no ranking de lançamentos na RMSP. É considerado o principal município da região industrial do $A B C D^{26}$ e o que possui maior renda per capita entre os três analisados. Possui uma grande parte de seu território em área de manancial e assistiu à perda de parte de seu parque industrial desde os anos 1980. Diante de tais transformações, a gestão municipal ofereceu incentivos à permanência e à instalação de novas plantas fabris no município, o que ocasionou uma forte disputa sobre o uso do solo urbano. Na sua seleção, foram considerados os efeitos da regulação urbanística que, aos olhos dos promotores imobiliários, tornou-se uma das mais restritivas do $A B C D$ e do quadro de 
"pós-desindustrialização" sobre o tipo, padrão e preço da oferta imobiliária residencial.

Ao longo do ciclo expansivo, ocorreu mudança no porte dos empreendimentos, quando, em 2007-2009, a média de unidades por empreendimento atingiu 168, com pequena redução, em 2010-2012, para 154. A verticalização foi crescente, com $98 \%$ das UHs lançadas no primeiro período, alcançando $100 \%$ no segundo, utilizando cotas de terrenos muito reduzidas de $34 \mathrm{~m}^{2}$ e $23 \mathrm{~m}^{2}$, respectivamente. No último triênio, ocorreram redução da oferta e um aumento discreto no porte dos empreendimentos, com média de $173 \mathrm{UHs}$. A cota de terreno foi reduzida ainda mais, para $22 \mathrm{~m}^{2}$, com $100 \%$ das unidades verticais.

No início do boom, o mercado foi marcado pela presença de terrenos industriais e de uma demanda local que estimularam o surgimento de oferta a preços inferiores a $\mathrm{R} \$ 130$ mil, $17,1 \%$ dos lançamentos em 2007, e 34,6\% em 2008. Porém, desde 2011, essa novidade cedeu lugar à oferta de preços superiores, refletindo os novos tetos do PMCMV. Em 2008, o mercado direcionou $50 \%$ do total de unidades ao segmento econômico, nas faixas de até R\$170 mil, e, em 2010, esta se elevou a 59\%, correspondendo às mudanças nos valores máximos de preços permitidos no Programa. A partir de 2012, as unidades de preços entre R\$130 mil e R\$170 mil deixaram de ser ofertadas, enquanto as de preços entre $\mathrm{R} \$ 170$ mil e $R \$ 350$ mil prevaleceram. Os lançamentos de unidades de preço superior a $\mathrm{R} \$ 350$ mil denotaram a elitização do mercado, em 2011 (26\%) e 2012 (33\%). Como em Guarulhos, houve queda na oferta entre 2013 e 2015, quando o município assistiu ao predomínio de lançamentos enquadrados nos segmentos econômico e médio do mercado. Em 2014, houve crescimento da oferta com preços superiores, acompanhando o aumento do teto do FGTS no âmbito do SFH. Mas, esta cedeu lugar, em 2015, às faixas superiores do segmento econômico, entre $R \$ 225$ mil e $R \$ 350$ mil. Sem consolidar a elitização de seu mercado, esta permaneceu como tendência e dependente do financiamento à demanda e da atuação e estratégias das grandes empresas.

No município, no primeiro triênio (20072009) do ciclo expansivo, as 10 primeiras das 42 empresas atuantes foram responsáveis por $71 \%$ das 12.079 UHs lançadas, enquanto, no triênio seguinte, as 10 primeiras das 41 atuantes concentraram apenas $58 \%$ das 8.912 UHs ofertadas. A concentração da oferta nas três primeiras também foi maior no primeiro período, de $36 \%$, ${ }^{27}$ retraindo para $24 \%{ }^{28}$ no seguinte. Já, no último triênio analisado, de 2013 a 2015, houve uma redução significativa no número de unidades lançadas e de empresas atuantes, tendo participado dos lançamentos em São Bernardo 24 empresas que responderam por 6.656 UHs. Às 10 maiores do ranking, segundo o número de unidades lançadas, coube $83 \%$ do total das UHs do triênio, mostrando aumento expressivo da concentração da produção. Nesse grupo das 10 maiores, apenas duas empresas eram de capital aberto, revelando uma presença bastante inferior à apresentada nos dois períodos anteriores, quando eram cinco. Complementa esse movimento, a saída de parte significativa de empresas de capital aberto no município. ${ }^{29}$ Também entre as 10 maiores, destacam-se cinco empresas de capital fechado e atuação local. ${ }^{30}$ Destas, somente três ${ }^{31}$ são tradicionais e de forte atuação em todos os períodos analisados. 
A subprefeitura da Mooca inclui um distrito (Tatuapé), que se destacou desde os anos 1980 como vetor tradicional do mercado imobiliário e polo de classe média alta na zona leste do MSP, e outros cinco distritos caracterizados pela estagnação imobiliária e que, recentemente, foram, em parte, atingidos pelo boom imobiliário, seja por influência daquele polo ou por sua proximidade com a área central do município, seja pela especificidade local do uso de terrenos de indústrias desativadas. Foi a primeira no ranking de subprefeituras do MSP em volume de unidades lançado entre 2000 e 2012 e, quando suplantada, perdeu duas posições. De 2007 a 2012, participou com 10,7\% do total lançado da RMSP, o que, no triênio 2013-2015, retraiu para 5,3\%. Para sua seleção, fatores locacionais pesaram, tais como as áreas das antigas indústrias, a vizinhança de imóveis encortiçados e deteriorados em áreas de ocupação antiga e a significativa proximidade aos locais de trabalho do centro da metrópole, cujas adjacências eram propícias à instalação de novos usos residenciais de padrão econômico, generalizados na expansão do mercado.

Na Mooca, como nas outras zonas selecionadas, observou-se o aumento acentuado do porte dos lançamentos, com auge entre 2010 e 2012, de 138 UHs por empreendimento, compatível com a verticalização da região. Isto significou a redução da cota de terrenos por unidade residencial (de $30,6 \mathrm{~m}^{2}$ para $\left.26,9 \mathrm{~m}^{2}\right)$, sendo esta bem inferior à média do MSP de $30,7 m^{2}$. No último triênio, ocorreram redução da oferta e uma pequena redução no porte (123) e na cota média de terreno por unidade $\left(20,3 \mathrm{~m}^{2}\right)$.

Nessa subprefeitura, nos triênios 20072009 e 2010-2012, ocorreram mudanças significativas no número de unidades ofertadas por faixas de preços, com expressiva redução, embora gradativa, do segmento de padrão econômico, que praticamente desapareceu a partir de 2012. Este retornará com preços reajustados em 2015, evidenciando a "popularização do mercado" da Mooca, convivente com setores consolidados dos estratos de mais alta renda. Em 2007, foi o auge da oferta (25\%) das unidades lançadas de preços entre $R \$ 65$ mil e $R \$ 130$ mil, e as unidades de preço entre $\mathrm{R} \$ 130$ mil e $\mathrm{R} \$ 170$ mil corresponderam a somente $17 \%$ do total, ambas desapareceram em 2012, ante as mudanças nos tetos do PMCMV. Já as de preços entre $R \$ 170$ mil e $R \$ 350$ mil. que participaram em níveis sempre superiores a $30 \%$ entre 2008 e 2011, despencaram a 16,5\% em 2012. Sempre presentes, as ofertas de preço superior a $\mathrm{R} \$ 350$ mil, com participação gradualmente ampliada desde 2008, alcançaram 77\% em 2012 (50\% acima de $\mathrm{R} \$ 500$ mil). No triênio 2013-2015, houve a redução na oferta, retraindo de mais de 10.000 UHs nos dois primeiros triênios para menos de 8.000 UHs. Em 2013, predominaram unidades lançadas de preço superior a R\$350 mil, com participação significativa das de preço acima de R\$750 mil. Na crise em 2015, a oferta liderada por empresas grandes de capital fechado privilegiou segmentos econômico (PMCMV) e médio.

Ao longo de todo o período analisado, os níveis de concentração da oferta entre as 10 maiores empresas atuantes na subprefeitura foram mantidos, de 65\%, em 2007-2009, e de 66\%, em 2010-2012 e em 2013-2015. A concentração nas três primeiras empresas do ranking foi crescente nos dois primeiros triênios: de $35 \%{ }^{32}$ e de $38 \%{ }^{33}$ do total das unidades lançadas, respectivamente, retraindo para 
$32 \%{ }^{34}$ no último triênio analisado. Mesmo para um mercado de grande concorrência, como o da Mooca, constatou-se um nível expressivamente elevado de concentração das atividades imobiliárias. Revelou-se, no último triênio analisado, uma redução tanto no volume da oferta quanto no conjunto das empresas atuantes, se comparado aos períodos anteriores: entre 2007 e 2009 foram lançadas 10.130 UHs por 47 empresas; entre 2010 e 2012, 10.473 UHs por 50; e entre 2013 e 2015, 7.761 UHs por 41. Desse conjunto, cinco são empresas de capital aberto, revelando pouca variação numérica com relação aos triênios do ciclo expansivo, de seis e quatro, respectivamente. Após o período de boom, parte significativa das empresas de capital aberto deixou de atuar na Mooca. ${ }^{35}$ Ainda assim, permaneceram atuantes 10 empresas de capital aberto, que responderam por $38 \%$ do total de unidades lançadas no último período analisado, de desaceleração da oferta na região.

\section{Considerações finais}

A dinâmica do setor de edificações no período analisado enfatiza as conexões da atividade com a conjuntura econômica, ou seja, o desempenho setorial tem uma condição pró-cíclica, com picos de crescimento nos momentos de auge da atividade econômica e decréscimos relevantes com sua redução. Isso mostra o fato de que as empresas dependem, sobremaneira, das condições favoráveis de aumento dos rendimentos reais da população, aumento do crédito, oferta de subsídios, etc. No Brasil isso significou a possibilidade de canalizar fundos públicos e semipúblicos para dinamizar o setor, já que, sem esses estímulos, o mercado financeiro/secundário não seria capaz de alavancar a produção para estratos de rendas média e baixa, tampouco em contexto de crise macroeconômica. Embora a abertura de capitais das empresas tenha aumentado sua capitalização, a sustentação do investimento dá-se, no pós-crise internacional de 2008, principalmente com os investimentos do PMCMV.

O ciclo de crescimento imobiliário na metrópole paulistana foi impulsionado pelas grandes empresas de capital aberto, que, ao ingressarem em novas localidades, introduziram preços para os lançamentos cujas variações, em grande medida, acompanharam os de setores de São Paulo de mercado mais consolidado. $E$ as empresas atuantes nessas novas fronteiras do mercado se beneficiaram dessa valorização imobiliária, uma vez que passaram a trabalhar com preços mais altos, ainda assim absorvidos pelo mercado. Esse encarecimento da moradia foi possível devido ao aumento da solvabilidade proporcionada pela abundância de recursos provenientes de fundos públicos e semipúblicos direcionados ao crédito e subsídios.

Constatou-se que os produtos mais baratos foram oferecidos pelas grandes empresas que protagonizaram o boom na RMSP, pois estas, na busca por maior rentabilidade, diversificaram o seu portfólio, atuando em diferentes segmentos e localidades. Todavia, as empresas menores apresentaram uma atuação local e regional, bem como uma diversidade quanto à sua perenidade, a depender do grau de consolidação do mercado e da capacidade de deslocamento pela RMSP. Esse comportamento ficou condicionado pelos arranjos produtivos e modelos de negócio que podem associar empresas com papéis e porte distintos, incluindo 
as parcerias com empresas de maior porte, de capital aberto ou fechado, bem como articuladas a outros setores econômicos.

Houve, também, uma tendência constante de aumento de preço das unidades acima dos índices inflacionários e dos rendimentos médios da população, o que incluiu as oferecidas às faixas de mercado do PMCMV. Foram observadas as sucessivas alterações para cima nos tetos do financiamento, o que sugere a inexistência de iniciativas de gestores do sistema financeiro e das administrações públicas nos vários níveis em contrarrestar essa tendência ao menos nas faixas subsidiadas direta e indiretamente. Isso significou, possivelmente, uma drenagem de parte dos recursos da política habitacional para os agentes beneficiados por maiores patamares de apropriação da renda fundiária especulativa. Tanto no período de boom quanto no período de desaceleração, o segmento econômico permaneceu, mesmo apresentando algumas oscilações nos preços dos produtos lançados, sendo restringido, a partir de 2012, no mercado da RMSP. Pode-se especular que a oferta ao segmento econômico situada nos intervalos de preço próximo a R\$200 mil (U\$100 mil) nos anos 2009, atualmente, encontra-se em patamares de preço identificados acima desse valor, descolando-se dos níveis que haviam sido praticados, adequados ao poder aquisitivo dos consumidores dessa faixa.

Com relação às dinâmicas do imobiliário no período analisado, identificou-se uma tendência homogeneizante que inclui produtos massificados e processos/estratégias dominantes capitaneados pelas grandes empresas durante o ciclo de expansão do setor. Além disso, no movimento de desaceleração e recessão, essa tendência deu lugar à reestruturação da incorporação imobiliária. Isso ocorre pela: saída de parte das grandes empresas dos novos vetores de expansão do mercado formal; redução da oferta do financiamento público, principalmente para os estratos de menor poder aquisitivo, e a emergência de arranjos híbridos, mesclando práticas pretéritas de promotores locais; e ajustes que envolvem padrão, preço e financiamento, assentados em patamares intermediários do mercado.

Em uma visão geral sobre a região, a falta de uma autoridade metropolitana ou de planos integrados entre os municípios dificultou uma distribuição regional adequada e a articulação da oferta de moradias com os déficits oficiais. Ademais, a falta de compatibilização entre as normas urbanísticas dos municípios e da governança metropolitana que, por sua vez, têm sido influenciadas pelos interesses empresariais resultou em procedimentos e parâmetros mais ou menos atrativos para as práticas dos promotores imobiliários, como a existência ou não de aplicação de instrumentos urbanísticos de controle de uso do solo, da captação de parte de lucros imobiliários pelo poder público e de exigência de contrapartidas para implantação de empreendimentos sob determinadas condições prescritas pelos planos diretores municipais. Os tipos, preços e localização dos empreendimentos na região foram decididos inteiramente pelas empresas privadas condicionadas pela oferta do crédito, e os aspectos regulatórios definidos pelos agentes financeiros, bem como por incentivos e benefícios obtidos no enlace entre setor público, nas esferas federal e municipal, e o complexo financeiro-imobiliário. 
Cumpre destacar que a oferta habitacional, ao longo do ciclo de expansão, não atendeu os segmentos de mais baixa renda. A aposta quase que exclusiva no acesso à casa própria promovida por agentes privados apoiados em uma política de crédito e subsídio inviabilizou a diversidade de soluções necessárias para o enfrentamento das distintas necessidades habitacionais presentes na metrópole paulistana. $\mathrm{E}$, além disso, ao potencializar movimentos especulativos sobre a terra urbana, intensificou o quadro de precariedade habitacional na base da pirâmide social.

\section{[I] hhttps://orcid.org/0000-0001-7339-4192}

Universidade Federal do ABC, Centro de Engenharia, Modelagem e Ciências Sociais Aplicadas/Bacharelado em Planejamento Territorial, Santo André, SP/Brasil.

Universidade Estadual de Campinas, Instituto de Economia/Centro de Estudos do Desenvolvimento Econômico, Campinas, SP/Brasil.

bea.mioto@gmail.com

\section{[II] https://orcid.org/0000-0002-1828-7615}

Universidade Federal do ABC, Centro de Engenharia, Modelagem e Ciências Sociais Aplicadas, Bacharelado em Planejamento Territorial. Santo André, SP/Brasil.

Universidade Federal de São Carlos, Programa de Pós-Graduação em Engenharia Urbana. São Carlos, SP/Brasil.

carolmcastro@gmail.com

[III] https://orcid.org/0000-0002-7754-6533

Universidade São Judas Tadeu, Faculdade de Arquitetura e urbanismo. São Paulo, SP/Brasil.

lesigolo@yahoo.com.br

\section{Notas}

(*) Este artigo se fundamenta, em parte, na pesquisa "Características da produção imobiliária formal nos anos 2000 e seus efeitos sobre o custo e condições de habitação na Região Metropolitana de São Paulo", financiada pelo Lincoln Institute of Land Policy (2015), com participação de Helena M. B. Silva (coordenação), Carolina M. P. de Castro, Lucia Z. Shimbo, Letícia M. Sígolo e Silvia M. Schor. Ademais, elaboram-se uma perspectiva macroeconômica e uma análise setorial sobre o mercado imobiliário da RMSP para o período de 2013 a 2015. 
(1) Cumpre observar que, nos anos 2000, completou-se a reforma do SFH, com a recuperação das principais fontes de financiamento imobiliário no País, constituídas no período do BNH, o FGTS e o SBPE, bem como alterações no arcabouço regulatório e resoluções do Conselho Monetário Nacional (CMN) e do Conselho Curador do FGTS (CCFGTS) que promoveram a ampliação de recursos destinados, bem como a redução dos juros incidentes, nos financiamentos dessa natureza (Royer, 2009).

(2) Selic -Taxa média dos financiamentos diários do Sistema Especial de Liquidação e de Custódia de títulos federais.

(3) PAC - Programa de Aceleração do Crescimento. PMCMV - Programa Minha Casa, Minha Vida.

(4) Dados compilados de releases mensais divulgados pela Fundação Instituto de Pesquisas Econômicas (Fipe) e a Associação Brasileira de Incorporadores Imobiliárias (Abrainc), que desenvolvem os indicadores Abrainc/Fipe para o mercado imobiliário.

(5) Caged- Cadastro Geral dos Empregados e Desempregados - Ministério do Trabalho e Emprego.

(6) Dados do Ministério das Cidades, posição novembro de 2013.

(7) Para esse cálculo, foram considerados os lançamentos residenciais listados pela Embraesp e a provisão habitacional pública municipal, estadual e federal na RMSP para o período.

(8) Os estratos populacionais rotulados pelos agentes promotores privados como "segmento econômico" eram atendidos pela oferta de unidades cujos preços variavam em torno de U\$100 mil ou R\$200 mil em 2009. Após o lançamento do Programa Minha Casa Minha Vida, a oferta enquadrada nos valores máximos das faixas de mercado do Programa, inicialmente, passou a ser denominada como constituinte do "segmento supereconômico"; mas, com os aumentos recorrentes dos "tetos", essa oferta enquadrada nos valores máximos do Programa passou a compreender quase que a totalidade do "segmento econômico". No MSP, por exemplo, esse segmento que abrangia faixas de renda de até 16 SM, segundo o PDE/2002, retraiu para até 10 SM, no PDE/2014, em razão da valorização real do salário mínimo nesse período.

(9) Sígolo (2014, p. 259) cita municípios da RMSP que receberam oferta do mercado formal nos anos 2000, constituindo-se como vetores de expansão e que se formaram a partir de assentamentos populares: a oeste: Carapicuíba e Barueri; a leste: Ferraz de Vasconcellos, Suzano, Itaquaquecetuba e Mogi das Cruzes; a norte: Cajamar; a sudoeste: Taboão da Serra e Cotia; e a Sudeste: Diadema e Mauá. Em São Paulo, os distritos: a leste: São Mateus, José Bonifácio, Lajeado, Vila Curuçá e Itaim Paulista; a sudoeste: Capão Redondo; e a norte: Jaraguá.

(10) INCC - Índice Nacional da Indústria da Construção (Sindicato da Indústria da Construção) e IPCA Índice de Preços ao Consumidor (Instituto Brasileiro de Geografia e Estatística).

(11) O preço máximo de imóvel a ser financiado com recursos do FGTS não pode ultrapassar o valor-limite de avaliação estabelecido para o SFH. Em 2009, esse limite de $\mathrm{R} \$ 350$ mil passou para $\mathrm{R} \$ 500$ mil; em 2013 para $\mathrm{R} \$ 750$ mil; e em 2015 para $\mathrm{R} \$ 900 \mathrm{mil}$.

(12) Entre 2009 e 2010, o valor máximo de financiamento nas faixas de mercado (2 e 3) do PMCMV, que era de $\mathrm{R} \$ 130$ mil, passou para $\mathrm{R} \$ 170$ mil em 2011; para $\mathrm{R} \$ 190$ mil em 2013; e para $\mathrm{R} \$ 225$ mil em 2015. 
(13) Em 2007, das 10 maiores, apenas duas empresas não eram de capital aberto: Goldfarb e Plano \& Plano; essa última, no entanto, associada à Cyrela; Em 2012, duas não apresentavam vínculos com outras de capital aberto: a Fibra (de 2004 e vinculada ao Grupo Vicunha, atuante nos setores têxtil, siderúrgico e financeiro) e a Atua (de 2007, vinculada à Yuny, com foco no segmento econômico); e em 2015, quatro: a Associação Comunitária e Cultural dos Trabalhadores em Asseio (também vinculada à Vicunha), a Econ (também vinculada à Yuny), a Engelux e a Plano \& Plano.

(14) Cohab-SP - Companhia Metropolitana de Habitação de São Paulo.

(15) São elas: Tenda, com 28,5\%; MRV, com 17\%; e Goldfarb, com 12,5\%.

(16) São elas: Paz/Bem Casa, com 24,7\%; PDG, com 18,7\%; e Rossi, com 13,6\%.

(17) São elas: Econ, com 15,6\%; Brookfield, com 13\%; e Tenda, com 11\%.

(18) São elas: Rossi, Tenda, Goldfarb/PDG, MRV e Brookfield.

(19) São elas: MRV, More Melhor Goldfarb, Trisul e Rossi

(20) São elas: Trisul, com 43,7\%; Tenda, com 33,3\%; e MRV, com $20 \%$.

(21) São elas: Cury, com 45,1\%; Tecnisa, com 23,4\%; e Rossi, com 13,9\%.

(22) São elas: G2, com 46,6\%; Bracco, com 20,5\%; e Genea, com 13,5\%.

(23) São elas: Tenda, MRV, Tecnisa, Cury e Rossi.

(24) São elas: MRV (31\%); Lindencorp+EzTec (22\%); Helbor/MPD (5\%); e OAS Empreendimentos (2,5\%). Destaca-se a entrada da OAS Empreendimentos, em 2013 (2,5\% do total de unidades e 2,7\% do VGV). A Invepar, subsidiária da OAS, foi responsável pela construção da ampliação do aeroporto internacional de Guarulhos e pela concessão, por 20 anos, do Terminal 3, desde 2012.

(25) São elas: Brookfield, Tenda/Fit/Gafisa, PDG, Queiroz Galvão, Tecnisa, Trisul, Even/Rossi, Kallas e Klabin Segal.

(26) A região do $A B C D$ é composta por sete municípios: Santo André, São Bernardo do Campo, São Caetano do Sul, Diadema, Mauá, Ribeirão Pires e Rio Grande da Serra.

(27) São elas: Agra/Fal 2+ Agra/Abyara + Agra /Fal 2/Pecos, com 18\%; Tenda + Gafisa + Fit, com 11\%; e Tecnisa Flex + Tecnisa/Abyara/Schahin, com 7\%, participantes de arranjos produtivos entre empresas de capital aberto.

(28) São elas: EzTec, com 9\%; MRV, com 8\%; e M Bigucci, com 7\%.

(29) São elas: Agra, Tenda, EzTec, Gafisa, MRV e Tecnisa.

(30) São elas: M Bigucci, Kabajá, Sammarone, Absoluta e Ekopar.

(31) São elas: M Bigucci, Sammarone e Absoluta.

(32) São elas: Goldfarb/PDG, com 16\%; Even, com 11\%; e Rossi, com $8 \%$.

(33) São elas: Cyrela+Cyrela/MAC+Cyrela/Magik, com 17\%; PDG+PDG/Planik, com 13\%; Fibra+Fibra Experts, com 8\%.

(34) São elas: Even, com 12,4\%, Yuny, com 11,9\%; e Paz Realty, com 7,7\%.

(35) São elas: PDG, Klabin Segal, OAS, Rossi, Goldfarb e Company. 


\section{Referências}

ALMEIDA, J. S. G.; NOVAIS, L. F. e ROCHA, M. A. (2016). A fragilização financeira das empresas não financeiras no Brasil pós-crise. Campinas, IE-Unicamp (Texto para Discussão).

BALTAR, P. et al. (2010). Moving towards decent work. Labour in the Lula Government: reflections on recent brazilian experience. Global Labour University Working Papers, n. 9. Berlim.

BARBOSA, N. e PEREIRA DE SOUZA, I. A. (2010). "A inflexão do governo Lula: política econômica, crescimento e distribuição de renda". In: SADER, E. e GARCIA, M. A. Brasil, entre o passado e o futuro. São Paulo, Boitempo.

BELLUZZO, L. G.; TAVARES, M. C. e FIORI, J. L. (2004). “A mundialização do capital e a expansão do poder americano”. In: FIORI, J. L. O poder americano. Petrópolis, Vozes.

BERTASSO, B. (2012). Edificações: impasses da modernização no ciclo de crescimento dos anos 2000. Tese de Doutorado. Campinas, Universidade Estadual de Campinas.

CASTRO, C. M. P. de (1999). A explosão do autofinanciamento na produção da moradia em São Paulo nos anos 90. Tese de Doutorado. São Paulo, Universidade de São Paulo.

CASTRO, C. M. P. de e SHIMBO, L. Z. (2011). O "Padrão Econômico" da Habitação: Construindo uma Trajetória de Mercado. In: ENCONTRO NACIONAL DA ANPUR, 14. Anais.... Rio de Janeiro, ANPUR.

CINTRA, M. A. M. (2007). Fundo de Amparo ao Trabalhador (FAT) e Fundo de Garantia do Tempo de Serviço (FGTS). Mimeo.

COUTINHO, L. e BELLUZZO, L. G. (1998). Financeirização da riqueza, inflação de ativos e decisões de gasto em economias abertas. Economia e Sociedade. Campinas, n. 11, pp. 137-150.

FIX, M. (2011). Financeirização e transformações recentes no circuito imobiliário no Brasil. Tese de Doutorado. Campinas, Instituto de Economia, Universidade Estadual de Campinas.

HIRATUKA, C. (coord.). (2010). Perspectiva do investimento na indústria. Projeto PIB. Campinas/Rio de Janeiro, Unicamp/UFRJ. Mimeo.

LOPREATO, F. L. C. (2018). Uma razão a mais para se pensar o porquê de a taxa de juros ser tão alta no Brasil. Campinas, IE/Unicamp (Texto para Discussão).

MEDEIROS, C. A. (2017). A economia brasileira no novo milênio: continuidade e mudanças nas estratégias de desenvolvimento. Revista de Economia Contemporânea. Rio de Janeiro, número especial, pp. 1-16.

MIOTO, B. T. (2015). As políticas habitacionais no subdesenvolvimento: os casos do Brasil, Colômbia, México e Venezuela (1980/2013). Tese de Doutorado. Campinas, Universidade Estadual de Campinas.

MIOTO, B. T. e PENHA FILHO, C. A. (2018). Crise econômica e o setor imobiliário no Brasil: um olhar a partir da dinâmica das maiores empresas de capital aberto (Cyrela, PDG, Gafisa e MRV). In: SEMINÁRIO FINANCEIRIZAÇÃO E ESTUDOS URBANOS: OLHARES CRUZADOS EUROPA E AMÉRICA LATINA, 1, São Carlos. Anais.... São Carlos, Instituto de Arquitetura e Urbanismo/Universidade de São Paulo.

PAULANI, L. M. (2016). Acumulação e rentismo: resgatando a teoria da renda de Marx para pensar o capitalismo contemporâneo. Revista de Economia Política, v. 36, n. 3, pp. 514-535. 
PENHA FILHO, C. A. e MIOTO, B. T. (2017). Limites da concentração e centralização do capital no imobiliário: um olhar a partir de quatro empresas incorporadoras. In: XVII ENCONTRO NACIONAL DA ANPUR. Anais ... São Paulo, Anpur.

PINTO et al. (2017). A guerra de todos contra todos: a crise brasileira. IE- UFRJ. Discussion paper, TD 006. Disponível em: http://bit.ly/2pXoEpl. Acesso em: 10 maio 2017.

ROYER, L. de O. (2009). Financeirização da política habitacional: limites e perspectivas. Tese de Doutorado. São Paulo, Universidade de São Paulo.

SíGOLO, L. M. (2014). O boom imobiliário na metrópole paulistana: o avanço do mercado formal de moradia em direção à periferia e a nova cartografia da segregação socioespacial. Tese de Doutorado. São Paulo, Universidade de São Paulo.

SILVA, H. M. B. (coord.). (2015). Características da produção imobiliária formal nos anos 2000 e seus efeitos sobre o custo e condições de habitação na Região Metropolitana de São Paulo. São Paulo, Lincoln Institute of Land Policy.

SMITH, N. (2008). Uneven development: nature, capital and the production of space. Athens, University of Georgia Press.

Texto recebido em $2 /$ jun/2018

Texto aprovado em 20/ago/2018 